\title{
Crustacean fauna (Stomatopoda: Decapoda) associated with the deepwater fishery of Heterocarpus vicarius (Decapoda: Pandalidae) along the Pacific coast of Costa Rica
}

\author{
Ingo S. Wehrtmann ${ }^{1,2,3}$ \& Silvia Echeverría-Sáenz ${ }^{1}$ \\ 1 Escuela de Biología, 2 Museo de Zoología y 3 Centro de Investigaciones en Ciencias del Mar y Limnología (CIMAR), \\ Universidad de Costa Rica, 2060 San José, Costa Rica; ingowehrtmann@gmx.de
}

Received 11-X-2005. C Corrected 08-VIII-2006. Accepted 16-III-2007.

\begin{abstract}
Commercial bottom trawling is a successful and commonly used method to catch marine shrimps. However, the shrimp fishing gears are poorly selective, and in addition to the target species they catch and retain large quantities of non-target species (bycatch). This study presents data concerning species composition and depth distribution of the crustacean fauna (stomatopods and decapods) associated with Heterocarpus vicarius catches from Pacific Costa Rica. A total of 74 samples (three to five 20 min-tows each month) were taken between January 2004 and December 2005 with commercial shrimp trawlers at depths varying between 192 and $350 \mathrm{~m}$. In all depth ranges analyzed, total catch of crustaceans was significantly higher than that of fishes. A total of 28 decapods and two stomatopod species were identified. In comparison to other bycatch composition of comparable fisheries in Latin America, the crustacean fauna of the $H$. vicarius fishery in Costa Rica is highly diverse. Most common species were Solenocera agassizii (Solenoceridae), Squilla biformis (Squillidae), Plesionika trispinus (Pandalidae), and Pleuroncodes sp. (Galatheidae), reaching total catch percentages of $57.2 \%, 81.5 \%, 91.8 \%$, and $99.6 \%$ of individual catches, respectively. The results presented herein may contribute to the development of responsible management strategies for the deepwater fisheries in Costa Rica and Central America. Rev. Biol. Trop. 55 (Suppl. 1): 121-130. Epub 2007 June, 29.
\end{abstract}

Key words: Heterocarpus vicarius, deepwater fishery, bycatch, Central America, eastern tropical Pacific.

Commercial bottom trawling is a successful and commonly used method to catch marine shrimps. These fishing activities are considered as one of the primary causes of physical perturbation to the seabed on the continental shelf and upper slope (Watling and Norse 1998, Bozzano and Sardà 2002). Typically, the shrimp fishing gears are poorly selective, and in addition to the target species they catch and retain large quantities of non-target species, so-called "bycatch" (Andrew and Pepperell 1992, Hall et al. 2000). Tropical shrimp trawl fisheries are considered to have the highest discard rate in the world's marine fisheries (Kelleher 2005). The ratio of bycatch to shrimps in tropical and subtropical zones is usually between $5: 1$ and 10:1 (FAO 1982, Harris and Poiner 1990). Bycatch may be used as food in some countries, however, in many others it is returned to the sea, either because of its size or because of poor commercial value (FAO 1982, Hill and Wassenberg 2000, Machias et al. 2001). Information concerning bycatch composition and discard rates are necessary to develop more intelligent ways to harvest our marine resources (Hall et al. 2000).

The ecology of deepwater shrimp species, their fishery and impact on the environment have been especially well studied in the Mediterranean (Marsan et al. 2000, Belcari et al. 2003, Sardà et al. 2003a, b, 2004, Castro et al. 2005, Chilari et al. 2005). In contrast, our knowledge regarding these topics in Latin 
America is far from complete. Concerning the Pacific, several studies have been published from Chilean waters, focusing on the pandalid shrimp Heterocarpus reedi (e.g., Bahamonde and Henríquez 1965, Andrade and Báez 1980, Roa and Ernst 1996, Arana et al. 2003b), the red royal shrimp Haliporoides diomedeae (Arana et al. 2003a and references therein), and the razor shrimp Campylonotus semistriatus (Arana and Ahumada 2006). Hendrickx (1996, 2001, 2003) provided insights concerning the presence of deepwater shrimps of the Gulf of California, and Hendrickx et al. (1998) reported data concerning growth, abundance, distribution and biochemical composition of $H$. vicarius from the southeastern Gulf of California. To our knowledge, there is no published information available regarding the fishery-biology of shrimps from deepwater zones of Pacific Central America.

Three deepwater decapod species are known to be commercially exploited along the Pacific coast of Central America (Holthuis 1980): Solenocera agassizii, Heterocarpus vicarius, and $H$. affinis. While the former two species may co-occur in depths ranging between 200 and $400 \mathrm{~m}, \mathrm{H}$. affinis is fished in considerably deeper waters (700-1 400 m; Holthuis 1980, Hendrickx 1995b). Heterocarpus vicarius is known to occur along the Pacific coast from the Gulf of California to Peru, and is commercially exploited in Costa Rica and Panama (Holthuis 1980, Hendrickx 1995b). Commercial landings of $H$. vicarius in Costa Rica peaked in 1993 with roughly 400 tons, then decreased substantially well below 100 tons per year, and increased again in 2004, reaching almost 300 tons (H. Araya, Instituto Costarricense de Pesca y Acuicultura, pers. comm.).

In order to facilitate the development of responsible management strategies for deepwater resources in the area, here we present data concerning species composition and depth distribution of the crustacean fauna (stomatopods and decapods) associated with $H$. vicarius catches from Pacific Costa Rica.

\section{MATERIALS AND METHODS}

Study site and sampling: The study area extended approximately from $08^{\circ} 38^{\prime} 02^{\prime \prime}$ to $10^{\circ} 32^{\prime} 10^{\prime \prime} \mathrm{N}$ and $84^{\circ} 05^{\prime} 54^{\prime \prime}$ to $86^{\circ} 10^{\prime} 42^{\prime \prime} \mathrm{W}$, covering the main fishing grounds for the target species, Heterocarpus vicarius; most samples were collected in the central Pacific region of Costa Rica $\left(09^{\circ} 26^{\prime} 46^{\prime \prime}\right.$ to $09^{\circ} 20^{\prime} 54^{\prime \prime} \mathrm{N}$ and $85^{\circ} 05^{\prime} 50^{\prime \prime}$ to $\left.84^{\circ} 36^{\prime} 16^{\prime \prime} \mathrm{W}\right)$. Bottom water temperatures and salinities were around 11.3$13.5^{\circ} \mathrm{C}$ and $34.9-35.1$ psu, respectively (I.S. Wehrtmann, unpubl. data).

A total of 22 monthly samples (Fig. 1) were taken between January 2004 and December 2005 with commercial shrimp trawlers equipped with two standard epibenthic nets; each net was $20.5 \mathrm{~m}$ long and had a mouth opening of $5.35 \times 0.85 \mathrm{~m}$. The mesh size was $4.45 \mathrm{~cm}$, that of the codend $3.81 \mathrm{~cm}$. During each month three to five 20 minutetows were carried out during daylight (74 samples in total) at a speed of 0.8-1.2 nm. All catch values refer to $\mathrm{kg}$ per 20-minute haul. The initial and final positions were recorded by a portable global satellite positioning system (GARMIN GPS 12 XL). Fishing depths were obtained from an installed echo-sounder, and varied between 192 and $350 \mathrm{~m}$. The location of the first haul was decision of the captain and was a place where he expected to find $H$. vicarius, generally between $250-300 \mathrm{~m}$ depth. The other hauls were carried out in the same fishing ground, but at least one slightly deeper (ca. 300-350 m) and another one slightly shallower (ca. 200-250 m) than the first tow. Depending on the amount of the catch, we sorted the entire material of both nets or only representative portions of the catch. The material was separated on deck into the following groups: H. vicarius (Pandalidae), Plesionika trispinus (Pandalidae), Solenocera agassizii (Solenoceridae), Stomatopoda, Galatheidae, fish and others. These groups were weighted on board, and weight values were expressed as percentage of the total catch. From each haul, several collected individuals of Stomatopoda, Galatheidae and the other uncommon groups 


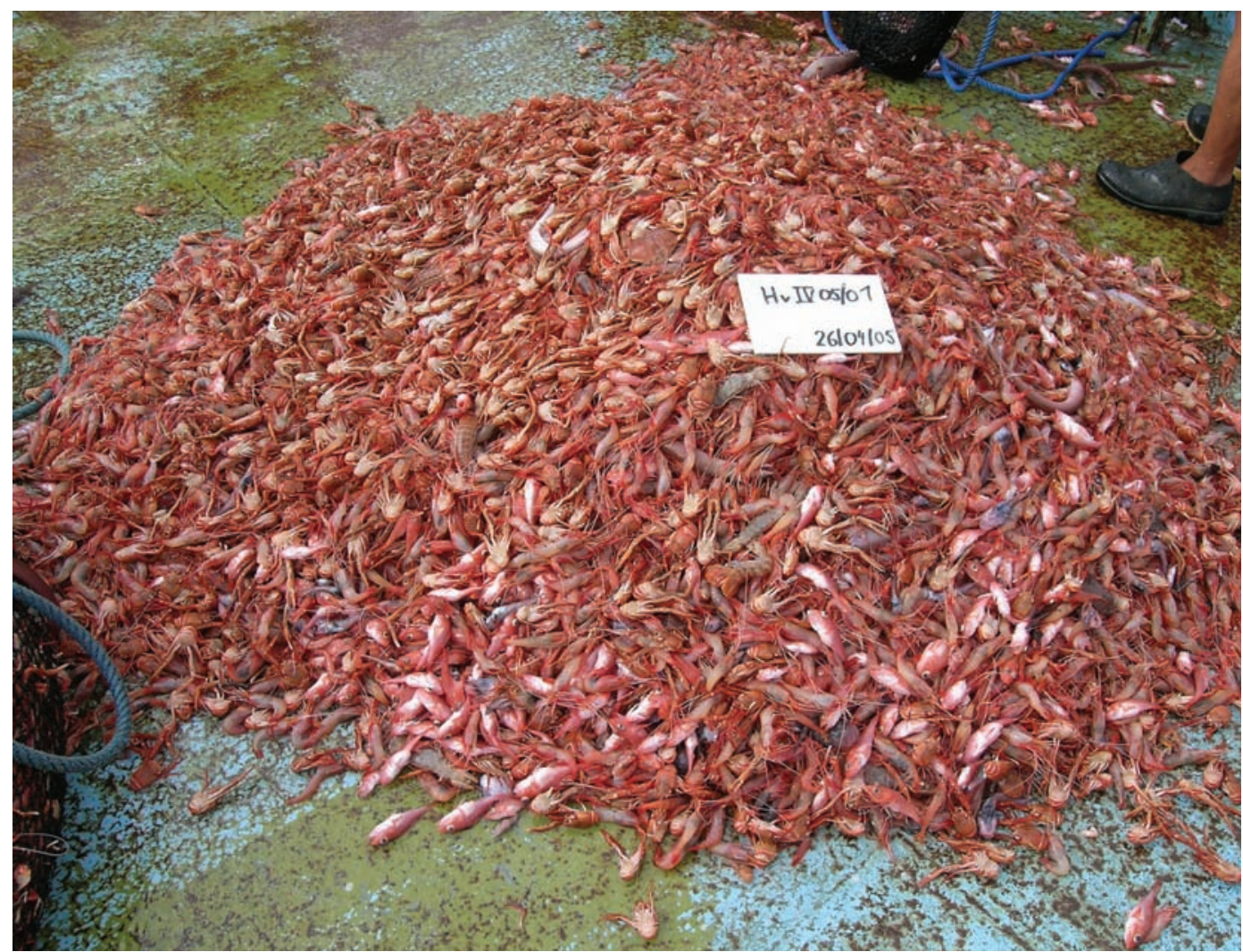

Fig. 1. Typical catch of Heterocarpus vicarius and associated fauna on board the shrimp trawler “Onuva”, December 2004, Pacific coast of Costa Rica.

were separated and frozen for further identification in the Museo de Zoología of the Universidad de Costa Rica in San José. For the identification we used the keys provided by Hendrickx (1995a, b, c, d) as well as other specific publications (e.g., Garth 1958, Haig 1960, Hendrickx and Salgado-Barragán 1991, Hendrickx and Estrada Navarette 1996, Hendrickx 1997, 2000, Martin and Davis 2001).

\section{RESULTS}

Mean total length of the target species, $H$. vicarius, and the other commercially exploited species, $S$. agassizii, was $89.5 \mathrm{~mm}(\mathrm{n}=14785)$ and $94.1 \mathrm{~mm}$ TL $(\mathrm{n}=9898)$, respectively. A total of 28 decapods and two stomatopod species were identified (Table 1); the latter were representatives of two different families (Hemisquillidae and Squillidae). Associated decapod species belonged to 22 families; Penaeoidea were represented by two species from two families, Caridea by four species from four families, Anomura by eight species from four families, and Brachyura by 14 species from ten families (Table 1). The family with the highest number of species encountered in the material was Galatheidae (4 spp.), followed by Calappidae (3 spp.). Most common species (occurring in more than $60 \%$ of all hauls; see Table 1) were Squilla biformis (Squillidae), Solenocera agassizii (Solenoceridae), Plesionika trispinus (Pandalidae), and Pleuroncodes sp. (Galatheidae).

Table 3 provides an overview of the total catch per group expressed as mean percentage from all hauls obtained between January 2004 
TABLE 1

Composition, depth range and occurrence of the associated crustacean fauna with the Heterocarpus vicarius-fishery along the Pacific coast of Costa Rica (January 2004 - December 2005).

Group

Stomatopoda

Caridea

Brachyura
Family

Hemisquillidae

Squillidae

Sicyoniidae

Solenoceridae

Glyphocrangonidae

Hippolytidae

Pandalidae

Pasiphaeidae

Diogenidae

Diogenidae

Dorippidae

Galatheidae

Galatheidae

Galatheidae

Galatheidae

Porcellanidae

Calappidae

Calappidae

Calappidae

Cancridae

Goneplacidae

Inachidae

Inachidae

Leucosiidae

Leucosiidae

Majidae
Species

Hemisquilla californiensis (Stephenson, 1967)

Squilla biformis Bigelow, 1891

Sicyonia picta Faxon, 1893

Solenocera agassizi Faxon, 1893

Glyphocrangon alata Faxon, 1893

Lysmata sp.

Plesionika trispinus Squires \&Barragán, 1976

Pasiphaea americana Faxon, 1893

Paguristes bakeri Holmes, 1900

Petrochirus californiensis Bouvier, 1895

Ethusa ciliatifrons Faxon, 1893

Munida gracilipes Faxon, 1893

Munida obesa Faxon, 1893

Munida refulgens Faxon, 1893

Pleuroncodes sp.

Porcellana hancocki Glassel, 1937

Acanthocarpus alexandri Stimpson, 1871

Hepatus kossmanni Newmann, 1878

Platymera gaudichaudii $\mathrm{H}$. Milne Edwards, 1837

Cancer johngarthi Carvacho, 1989

Oediplax granulata Rathbun, 1893

Paradasygyius depressus (Bell, 1835)

Stenorynchus debilis (Smith, 1871)

Iliacantha hancocki Rathbun, 1935

Persephona orbicularis Bell, 1855

Maiopsis panamensis Faxon, 1893
Depth range (m)

Occurrence

273

rare

201-331

very common

201-274

common

229-309

very common

209

rare

232-275

rare

229-326

very common

216-339

273

293

220-311

220-300

229-313

229-274

229-339

256-284

339

256-293

201-339

common

occasional

311-339

occasional

rare

298-339

occasional

220-339

common

201-313

occasional 
TABLE 1 (Continued)

Composition, depth range and occurrence of the associated crustacean fauna with the Heterocarpus vicarius-fishery along the Pacific coast of Costa Rica (January 2004 - December 2005).

$\begin{array}{cccc}\text { Mithracidae } & \begin{array}{c}\text { Stenocionops ovata (Bell, 1835) } \\ \text { Palicidae }\end{array} & \text { 216-256 } & \text { occasional } \\ \text { Parthenopidae } & \begin{array}{c}\text { Palicus fragilis (Rathbun, 1893) } \\ \text { Parthenope (Platylambrus) exilipes } \\ \text { (Rathbun, 1893) }\end{array} & 273-275 & \text { occasional } \\ \text { Portunidae } & \begin{array}{c}\text { Portunus iridescens (Rathbun, } \\ \text { 1893) }\end{array} & \text { 216-276 } & \text { rare } \\ & \quad & & \text { occasional }\end{array}$

very common $=$ in $>60 \%$ of hauls; common $=$ in $>30 \%$ of hauls; occasional $=$ in $>15 \%$ of hauls; rare $=$ in $<15 \%$ of hauls

TABLE 2

Comparison of crustacean species and family numbers recorded as bycatch from the Heterocarpus reedi - fishery in Chile (J.C. Orellana, unpubl. data) and H. vicarius - fishery in Costa Rica.

\begin{tabular}{lcccc} 
Group & \multicolumn{2}{c}{ Species } & \multicolumn{2}{c}{ Families } \\
Chile & Costa Rica & Chile & Costa Rica \\
Stomatopoda & 1 & 2 & 1 & 2 \\
Penaeoidea & 1 & 2 & 1 & 2 \\
Caridea & 2 & 4 & 2 & 4 \\
Palinura & 2 & 0 & 2 & 0 \\
Anomura & 4 & 8 & 2 & 4 \\
Brachyura & 5 & 14 & 5 & 10 \\
Total & $\mathbf{1 5}$ & $\mathbf{3 0}$ & $\mathbf{1 3}$ & $\mathbf{2 2}$
\end{tabular}

TABLE 3

Representation of taxonomic groups (mean weight percentage of total catch during January 2004- December 2005) associated with the Heterocarpus vicarius - fishery along the Pacific coast of Costa Rica.

$\begin{array}{ll}\text { Fish } & 25 \% \\ \text { Stomotopoda } & 19 \% \\ \text { Heterocarpus vicarius } & 18 \% \\ \text { Galatheidae } & 17 \% \\ \text { Solenocera agassizi } & 5 \% \\ \text { Others } & 2.5 \% \\ \text { Plesionika trispinus } & 14 \%\end{array}$

and December 2005. Fishes, stomatopods and the target species $H$. vicarius, were the most important taxa regarding total catch, followed by the squat lobsters (Galatheidae), and the pandalid species, P. trispinus. Solenocera agassizii comprised $5 \%$ of the total catch, and all the remaining species represented $2.5 \%$.
Crustaceans were predominant (in terms of weight of the total catch) in all three depth ranges (Fig. 2; 200-250 m: ANOVA, F 5.19; $\mathrm{p}<0.05$; 250-300 m: ANOVA, F 5.64; $\mathrm{p}<0.05$; 300-350 m: ANOVA, F 9.33; $\mathrm{p}<0.01)$. Highest total catch percentages from deeper waters (>300 m) were obtained for stomatopods, 


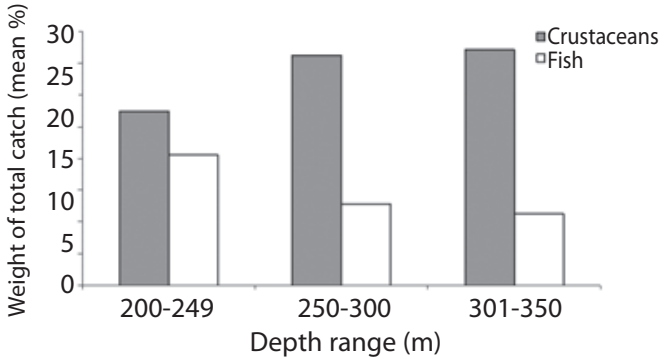

Fig. 2. Mean total catch percent per depth range of crustaceans and fish associated with the Heterocarpus vicariusfishery along the Pacific coast of Costa Rica (January 2004 - December 2005).

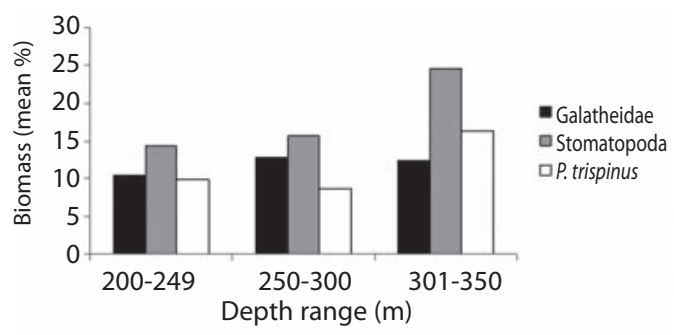

Fig. 3. Mean total catch percent per depth range of Galatheidae, Stomatopoda, and Plesionika trispinus associated with the Heterocarpus vicarius-fishery along the Pacific coast of Costa Rica (January 2004 - December 2005).

principally represented by Squilla biformis (Squillidae). The mean weight percentages for stomatopods increased gradually with depth and reached a maximum in hauls carried out at depth $>300 \mathrm{~m}$ (24.5\% of the total catch caught in this depth range; Fig. 3). Maximum total catch percentage for stomatopods was $81.5 \%$ in a haul carried out in May 2005 at $331 \mathrm{~m}$. Although the mean weight percentage of squat lobsters (Galatheidae) was almost identical in all three depth ranges (varying between 12.3 and $13.5 \%$; Fig. 3), in three occasions they made up practically the entire catch of the haul: February 2004 (92.8 \%; 318 kg; 339 m), November 2004 (99.6 \%; 2288 kg; 276 m), and April 2005 (92.3%; 479 kg; 220 m). For P. trispinus, highest (16.2 \%) and lowest mean percentage values $(9.1 \%)$ were obtained from hauls between 301-350 m and 250-300 m, respectively. However, almost entire individual hauls could consist of $P$. trispinus (September
2004: $91.8 \%$; 1585 kg; 242 m; August 2005: $87.6 \%, 495 \mathrm{~kg}, 201 \mathrm{~m}$ ).

The target species, $H$. vicarius, predominated in terms of weight in catches carried out between 250 and $300 \mathrm{~m}$ depth (Fig. 4). The highest concentration of the target species was in an individual haul at $267 \mathrm{~m}$ (October 2004; $106 \mathrm{~kg} ; 70.5 \%$ of total catch) closely followed by a haul carried out in December 2004 at 280 m with $70.2 \%$ of the total catch $(135 \mathrm{~kg})$. In six additional occasions $H$. vicarius constituted more than $60 \%$ (range: 61.1-65.8\%) of the total catch per haul obtained from depths varying between 284 and $311 \mathrm{~m}$.

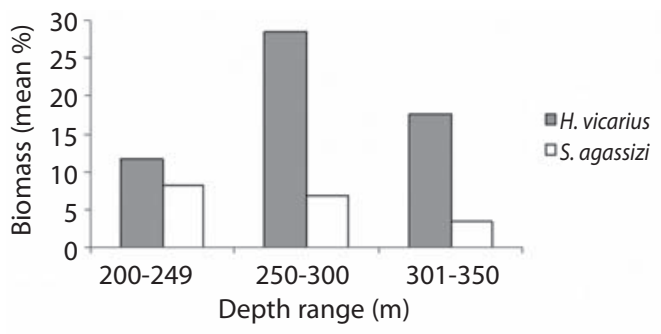

Fig. 4. Mean total catch percent per depth range of Heterocarpus vicarius and Solenocera agassizi in trawls carried out along the Pacific coast of Costa Rica (January 2004 - December 2005).

The second commercially important species, S. agassizii, showed a gradual decrease of mean weight with increasing depth (Fig. 4), varying between $8.7 \%$ and $5.3 \%$ of the total catch per depth range. The highest concentration refers to a haul carried out in August 2005 at $238 \mathrm{~m}$ depth, where $S$. agassizii comprised $57.2 \%$ of the total catch; in additional five occasions, the species made up roughly a third of the total catch (range: 26.4 - $31.6 \%$ ) from depths ranging between 229 and $293 \mathrm{~m}$.

\section{DISCUSSION}

Crustaceans clearly dominated the catches of Heterocarpus vicarius: $75 \%$ of the total catch were decapods and stomatopods, and only $25 \%$ was comprised by fishes (Table 3). Almost identical percentages have been reported from the fishery of Heterocarpus reedi in 
Chile (Arana et al. 2003b), a species which is commercially exploited in similar depth ranges as $H$. vicarius (Bahamonde and Henríquez 1965, Arana et al. 2003b). Although fish and crustaceans were the dominant megafaunal groups in deep sea areas of the Mediterranean, decapod biomass was higher only at depths $>1500$ m (Company et al. 2004). These discrepancies with the above-mentioned data regarding Heterocarpus spp. fisheries may be related to the different environmental conditions, especially to the oligotrophic nature of the Mediterranean.

Wicksten (1989) listed a total of 183 deepwater $(>200 \mathrm{~m})$ crustacean species for the eastern Pacific Ocean, of which 100 occur within the limits of the eastern tropical Pacific (Hendrickx 1996). Thus, species encountered as bycatch in $H$. vicarius hauls in Costa Rica represent $30 \%$ of the crustacean deepwater fauna of the entire eastern tropical Pacific. Hendrickx (1996) analyzed the biodiversity of decapod crustaceans in the SE Gulf of California, Mexico, and reported 19 decapod species from the upper slope (200- 1200 $\mathrm{m})$. The major difference in species numbers between both studies refers to Brachyura: while only three species of Brachyura were found in deepwater areas of the SE Gulf of California, Mexico (Hendrickx 1996), our study revealed the presence of 14 species (Table 1). More recently, Hendrickx (2001) reported a total of 31 species collected between 550 and $2250 \mathrm{~m}$ in the SE Gulf of California, Mexico, including just one brachyuran crab species and 13 species of Caridea, considerably more than in our study (4 spp.). However, both studies conducted in the SE Gulf of California (Hendrickx 1996, 2001) included the fauna of considerably deeper depth intervals than our study, thus making more detailed comparisons difficult. Species number can also be compared to the crustacean fauna associated to Pandalus platyceros catches in Baja California, Mexico, which were carried out in depths between 90 and $290 \mathrm{~m}$. According to Flores et al. (2004), the associated fauna was comprised by a total of nine crustacean species: two stomatopods and seven decapods. In shallower waters, Branco and Fracasso (2004) reported 28 decapod species associated with the Xiphopenaeus kroyeri fishery in southern Brazil, and Pérez-Barros et al. (2004) found 16 decapod species in catches of Munida spp. in the Beagle Channel, Argentina.

The crustacean fauna of the $H$. vicarius fishery in Costa Rica is highly diverse when compared to other bycatch compositions of comparable fisheries in Latin America. Species numbers of decapods are almost three times higher than in the $H$. reedi fishery off Chile where the associated decapod fauna is comprised by a total of 11 species (Arana et al. 2003b). More recently, however, J.C. Orellana (pers. comm.) listed a total of 14 decapod species as bycatch from the Chilean $H$. reedi fishery (Table 2). Interestingly, Andrade and Báez (1980) studied the decapod crustaceans caught with the $H$. reedi fishery during 1976 and 1979 in Chile and reported a total of 23 decapods, considerably more species than encountered during the more recent surveys (Arana et al. 2003b, J.C. Orellana, pers. comm.).

The crustacean fauna associated with the two Heterocarpus fisheries in Latin America ( $H$. reedi in Chile, $H$. vicarius in Costa Rica) has only one species in common: the caridean shrimp Glyphocrangon alata, known to occur in Pacific deepwater zones from Mexico to Chile. According to Hendrickx (1995b), this species can be found between 600 and 1325 $\mathrm{m}$, while our single individual was caught at a depth of 209 m, substantially shallower than the previously indicated depth range. Apart from G. alata, representatives of three genera (Pleuroncodes, Munida, and Cancer) were encountered in both fisheries. In general, the associated fauna in Costa Rica contained twice as many species per taxonomic group as the Heterocarpus-fishery in Chile (Table 2). There are, however, two exceptions: (1) two species of Palinura were reported from Chile, while none representative of this infraorder was collected in our study; (2) the species number of brachyuran crabs was three times higher than in Chile (Table 2). The absence of representatives of Palinura in our study is not surprising, 
since these species have not been reported from deepwater zones along the Pacific coast of Costa Rica. The fact that considerably more brachyuran species were encountered in our samples compared to those in Chile may reflect higher species diversity in deepwater zones of Central America.

The information presented herein may contribute to a better understanding of the deepwater fishery in Central America and its impacts on benthic communities, thus favoring the development of responsible management strategies for deepwater resources in the area.

\section{ACKNOWLEDGMENTS}

The study was part of a project about standards for a sustainable deepwater shrimp fishery in Pacific Costa Rica, which received funding from the German Government (Ministerium für wirtschaftliche Zusammenarbeit und Entwicklung, BMZ) and the Ristic AG (Oberferrieden, Germany). Additional support came from the Universidad de Costa Rica (project \# V.I. 111-A4-508). Special thanks to the captain (Rigoberto Villalobos Cruz) and the crew of the shrimp trawler "Onuva” as well as to Ronny Gründler, The Rainbow Jewels, (Puntarenas, Costa Rica). We are more than grateful to all the students who helped us during the fieldwork. We appreciate the help provided by Juan Bautista Chavarría (Universidad de Costa Rica, Escuela de Estadística) and Rita Vargas (Universidad de Costa Rica, Museo de Zoología) concerning statistical analyses and species identification, respectively. Patricio Arana sent us valuable literature for the discussion.

\section{RESUMEN}

Las redes de arrastre son un método exitoso y comúnmente utilizado para la pesca de camarones marinos. Sin embargo, son poco selectivas y, junto con las especies comerciales, se pesca también grandes cantidades de otras especies (fauna acompañante). Este estudio presenta información acerca de la composición y distribución batimétrica de los crustáceos (estomatópodos y decápodos) asociados con las capturas de Heterocarpus vicarius en el Pacífico de
Costa Rica. Entre enero del 2004 y diciembre de 2005, se tomaron 74 muestras en profundidades de 192-350 m (tres a cinco arrastres de 20 min cada mes), utilizando redes de arrastre comercial dirigidas a la pesca de camarones. En todos los intervalos de profundidad analizados, las capturas (kg) de crustáceos fueron significativamente mayores que las de los peces. Se identificaron 28 especies de decápodos y dos de estomatópodos. Al comparar la composición de especies de fauna acompañante de $H$. vicarius en Costa Rica con otras pesquerías de camarones en América Latina, se encuentra que la fauna de crustáceos es muy diversa. Las especies más comunes fueron Solenocera agassizii (Solenoceridae), Squilla biformis (Squillidae), Plesionika trispinus (Pandalidae) y Pleuroncodes sp. (Galatheidae), alcanzando porcentajes máximos de concentración - en un sólo arrastre - de hasta 57.2 \%, $81.5 \%$, 91.8 \% y $99.6 \%$ de la captura, respectivamente. Los resultados presentados aquí pueden contribuir al desarrollo de estrategias de manejo responsable para las pesquerías de aguas profundas en Costa Rica y en Centroamérica.

Palabras clave: Heterocarpus vicarius, pesquería de aguas profundas, fauna acompañante, América Central, Pacífico este tropical.

\section{REFERENCES}

Andrade, H. \& P. Báez. 1980. Crustáceos decápodos asociados a la pesquería de Heterocarpus reedi Bahamonde, 1955 en la zona central de Chile. Bol. Mus. Nac. Hist. Nat. Chile 37: 261-267.

Andrew, N.L. \& J.G. Pepperell. 1992. The by-catch of shrimp trawl fisheries, p. 527-565. In M. Barnes, A.D. Ansell \& R.N. Gibson (eds.). Oceanogr. Mar. Biol. Ann. Rev. 30. University of California Press, Berkeley, California, USA.

Arana, P.M. \& M. Ahumada. 2006. Camarón navaja (Campylonotus semistriatus), crustáceo de aguas profundas frente a la costa central de Chile (Crustacea, Decapoda, Campylonotidae). Invest. Mar., Valparaíso 34: 3-14.

Arana, P.M., M.Ahumada \&A. Guerrero. 2003a. Distribución y abundancia de la gamba Haliporoides diomedeae (Crustacea: Decapoda: Penaeidae) frente a la costa central de Chile. Invest. Mar., Valparaíso 31: 57-71.

Arana, P., M. Ahumada, A. Guerrero, S. Palma, T. Melo, D. Queirolo, R. Bahamonde, M. A. Barbieri \& C. Canales. 2003b. Evaluación directa de camarón nailon entre la II y VII Regiones, año 2003 (Proyecto FIP No 2003-05). Informe PreFinal. Estud. Doc, Pont. Univ. Católica Valparaíso 25/2003. 297 p. 
Bahamonde, N. \& G. Henríquez. 1965. Sinopsis de datos biológicos sobre el camarón nailon Heterocarpus reedi Bahamonde, 1955. Santiago, Chile, FAO Fish. Synop. 107: 1607-1627.

Belcari, B., C. Viva, M. Mori \& S. De Ranieri. 2003. Fishery and biology of Aristaeomorpho foliacea (Risso, 1827) (Crustacea: Decapoda) in the northern Tyrrhenian Sea (western Mediterranean). J. Northw. Atl. Fish. Sci. 31: 195-204.

Bozzano, A. \& F. Sardà. 2002. Fishery discard consumption rate and scavenging activity in the northwestern Mediterranean Sea. ICES J. Mar. Sci. 59: 15-28.

Branco, J.O. \& H.A.A. Fracasso. 2004. Ocorrencia e abundancia da carcinofauna acompanhante na pesca do camarao sete-barbas, Xiphopenaeus kroyeri Heller (Crustacea, Decapoda), na Armacao do Itapocoroy, Penha, Santa Catarina, Brasil. Rev. Brasil. Zool. 21: 295-301.

Castro, M., A. Araújo \& P. Monteiro. 2005. Fate of discards from deep water crustacean trawl fishery off the south coast of Portugal. New Zealand J. Mar. Freshwat. Res. 39: 437-446.

Chilari, A., M. Thessalou-Legaki \& G. Petrakis. 2005. Population structure and reproduction of the deep-water shrimp Plesionika martia (Decapoda: Pandalidae) from the eastern Ionian Sea. J. Crust. Biol. 25: 233-241.

Company, J.B., P. Maiorano, A. Tselepidies, C.-Y. Politou, W. Plaity, G. Rotllant \& F. Sardà. 2004. Deep-sea decapod crustaceans in the western and central Mediterranean Sea: preliminary aspects of species distribution, biomass, and population structure. Sci. Mar. 68 (Suppl. 3): 73-86.

FAO, 1982. Fish By-Catch - Bonus from the Sea. Report of a Technical Consultation on Shrimp By-Catch Utilization held in Georgetown, Guayana, 27/30 October 1981. IDRC, Ottawa, Ontario, Canada. $163 \mathrm{p}$.

Flores, J., M.E. Hendrickx \& H. Chapa-Saldaña. 2004. Capturas del camarón mancha blanca, Pandalus platyceros Brandt, 1851 (Caridea: Pandalidae), en la costa oeste de Baja California, México, con una breve revisión de su biología y su pesca, p. 199-211. In M.E. Hendrickx (ed.). Contributions to the Study of East Pacific Crustaceans 3, Inst. Cienc. Mar. Limnol, UNAM, México. 245 p.

Garth, J.S. 1958. Brachyura of the Pacific coast of America, Oxyrhyncha. Allan Hancock Pac. Exp. Univ. South. Cal. Press. Vol 21, Parts I \& II. 854 p.
Haig, J. 1960. The Porcellanidae (Crustacea Anomura) of the eastern Pacific. Allan Hancock Pac. Exp. Univ. South. Cal. Press. Vol 24. 440 p.

Hall, M., D.L. Alverson \& K.I. Metuzals. 2000. By-catch: problems and solutions. Mar. Pollut. Bull. 41: 204-219.

Harris, A.N. \& I.R. Poiner. 1990. By-catch of the prawn fishery of Torres Strait; composition and partitioning of the discards into components that float or sink. Aust. J. Mar. Freshwater Res. 41: 37-52.

Hendrickx, M.E. 1995a. Estomatópodos, p. 355-382. In W. Fischer, F. Krupp, W. Schneider, C. Sommer, K.E. Carpenter \& V.H. Niem (eds.). Guía FAO para la identificación de especies para los fines de la pesca. Pacífico centro-oriental. Volumen I. Plantas e invertebrados. FAO, Rome, Italy.

Hendrickx, M.E. 1995b. Camarones, p. 417-538. In W. Fischer, F. Krupp, W. Schneider, C. Sommer, K.E. Carpenter \& V.H. Niem (eds.). Guía FAO para la identificación de especies para los fines de la pesca. Pacífico centro-oriental. Volumen I. Plantas e invertebrados. FAO, Rome, Italy.

Hendrickx, M.E. 1995c. Anomuros, p. 539-564. In W. Fischer, F. Krupp, W. Schneider, C. Sommer, K.E. Carpenter \& V.H. Niem (eds.). Guía FAO para la identificación de especies para los fines de la pesca. Pacífico centro-oriental. Volumen I. Plantas e invertebrados. FAO, Rome, Italy.

Hendrickx, M.E. 1995d. Cangrejos, p. 565-636. In W. Fischer, F. Krupp, W. Schneider, C. Sommer, K.E. Carpenter \& V.H. Niem (eds.). Guía FAO para la identificación de especies para los fines de la pesca. Pacífico centro-oriental. Volumen I. Plantas e invertebrados. FAO, Rome, Italy.

Hendrickx, M.E. 1996. Habitats and biodiversity of decapod crustaceans in the SE Gulf of California, Mexico. Rev. Biol. Trop. 44: 603-617.

Hendrickx, M.E. 1997. Los cangrejos braquiuros (Crustacea: Decapoda: Dromiidae, hasta Leucosiidae). Inst. Cienc. Mar Limnol., Univ. Nal. Autón. México y CONABIO. México. 178 p.

Hendrickx, M.E. 2000. The genus Munida Leach (Crustacea, Decapoda, Galatheidae) in the eastern tropical Pacific, with description of two new species. Bull. Inst. Roy. Sci. Nat. Belgique 70: 163-192.

Hendrickx, M.E. 2001. Occurence of a continental slope decapod crustacean community along the edge of the minimum oxygen zone in south eastern Gulf of California, Mexico. Belg. J. Zool. 131: 95-109. 
Hendrickx, M.E. 2003. Size and abundance of deep water shrimps on the continental slope of the SE Gulf of California, Mexico, p. 227-234. In M.E. Hendrickx (ed.). Contributions to the Study of East Pacific Crustaceans 3, Inst. Cienc. Mar. Limnol, UNAM, México. 303 p.

Hendrickx, M.E. \& J. Salgado-Barragán. 1991. Los estomatópodos (Crustacea: Hoplocarida) del Pacífico Mexicano. Inst. Cienc. Mar Limnol., Univ. Nal. Autón. México, Publ. Esp. 10: 1-200.

Hendrickx, M.E. \& F.D. Estrada Navarrete. 1996. Los camarones pelágicos del Pacífico mexicano (Dendrobrachiata y Caridea). Inst. Cienc. Mar Limnol., Univ. Nal. Autón. México y CONABIO. México. 157 p.

Hendrickx, M.E., F. Páez-Osuna \& H.M. Zazueta-Padilla. 1998. Biology and biochemical composition of the deep-water shrimp Heterocarpus vicarius Faxon (Crustacea: Decapoda: Caridea: Pandalidae) from the southeastern Gulf of California, Mexico. Bull. Mar. Sci. 63 : 265-275.

Hill, B.J. \& T.J. Wassenberg. 2000. The probable fate of discards from prawn trawlers fishing near coral reefs. A study in the northern Great Barrier Reef, Australia. Fish. Res. 48: 277-286.

Holthuis, L.B. 1980. Shrimps and prawns of the world. An annotated catalogue of species of interest to fisheries. FAO Fish. Synop.125: 1-271.

Kelleher, K. 2005. Discards in the world's marine fisheries. An update. FAO Fish. Techn. Pap. 470: 1-131.

Machias, A., V. Vassilopoulou, D. Vatsos, P. Bekas, A. Kallianiotis, C. Papaconstantinou \& N. Tsimenides. 2001. Bottom trawl discards in the northeastern Mediterranean Sea. Fish. Res. 53: 181-195.

Marsan, R., N. Ungaro, C.A. Marano \& M.C. Marzano. 2000. Remarks on distribution and fishery biology of some Plesionika species (Decapoda, Pandalidae) in the southern Adriatic basin (Mediterranean Sea), p. 763-769. In J.C. von Vaupel Klein \& F.R. Schram (eds.). The Biodiversity Crisis and Crustacea. Proceedings of the Fourth International Crustacean Congress. A.A. Balkema, Rotterdam, The Netherlands.

Martin, J. \& G. Davis. 2001. An updated classification of the recent Crustacea. Natural History Museum of Los Angeles County, Science series no. 39. 132 p.

Pérez-Barros, P., F. Tapella, M.C. Romero, J.A. Calcagno \& G.A. Lovrich. 2004. Benthic decapod crustaceans associated with captures of Munida spp. (Decapoda: Anomura) in the Beagle Channel, Argentina. Sci. Mar. 68: 237-246.

Roa, R. \& B. Ernst. 1996. Age structure, annual growth, and variance of size-at-age of the shrimp Heterocarpus reedi. Mar. Ecol. Progr. Ser. 137: 59-70.

Sardà, F., J.B. Company \& A. Castellón. 2003a. Intraspecific aggregation structure of a shoal of a western Mediterranean (Catalan coast) deep-sea shrimp, Aristeus antennatus (Risso, 1816) during the reproductive period. J. Shellfish Res. 22: 569-579.

Sardà, F., J.B. Company \& F. Maynou. 2003b. Deepsea shrimp Aristeus antennatus Risso, 1816 in the Catalan Sea, a review and perspectives. J. Northw. Atl. Fish Sci. 31: 127-136.

Sardà, F., G. D’Onghia, C.Y. Politou, J.B, Company, P. Maiorano \& K. Kapiris. 2004. Deep-sea distribution, biological and ecological aspects of Aristeus antennatus (Risso, 1816) in the western and central Mediterranean Sea. Sci. Mar. 68 (Suppl. 3): 117127.

Watling, L. \& E.A. Norse. 1998. Disturbance of the seabed by mobile fishing gear: a comparison to forest clearcutting. Conserv. Biol. 12: 1180-1197.

Wicksten, M.K. 1989. Ranges of offshores decapod crustaceans in the eastern Pacific Ocean. Transact. San Diego Soc. Nat. Hist. 21: 291-316. 